\title{
Organization of the Volume
}

\author{
BETH BARON
}

The chapters in this volume move from the distant to the more recent past, with those on the modern period arranged by region. Some periods and places receive more attention than others. Occasional clustering, based on a relative abundance of sources and of scholars in certain fields, provides depth as well as breadth for these societies, such as Mamluk and modern Egypt. The volume deals with major aspects of Middle Eastern women's history, and the theme of male and female boundaries runs throughout. The chapters, most written by historians or using a historical approach, suggest that gender boundaries in the Middle East have been neither fixed nor immutable.

Nikki Keddie introduces the volume with a survey of major questions in Middle Eastern women's history that emphasizes the Muslim majority. By sketching shifts in women's position from ancient to modern times, she helps to identify ideological and other problems in the field and to suggest useful directions for future research. Deniz Kandiyoti provides a comparative context for the Middle East, contrasting systems of male dominance in two regions that Islam crosses, the first in sub-Saharan Africa and the second in the Middle East and southern and eastern Asia. She finds that most women in the second region tacitly agreed to a family pattern she calls "classical patriarchy" in which they were subordinate as young brides in return for later benefits. Kandiyoti suggests that Middle Eastern gender relations have been influenced by a particular conjunction of classic patriarchy and Islam.

The next set of chapters looks at women and gender in the first centuries of Islam. Leila Ahmed documents the tension between two tendencies: a legal one, sometimes called orthodox, stressing gender inequalities and a spiritual, or unorthodox one based on ethical egalitarianism. The latter, expressed in Sufism and other unorthodox movements such as Qarmatism, gave greater scope and freedom to women. Yet the legal current prevailed, and with it a rigidification of 
gender boundaries. Denise Spellberg focuses on changing views of 'A'isha, Muhammad's favorite wife and a model for Muslim women. She shows how ninth-century historians used 'A'isha's defeat in the Battle of the Camel to point out the dangers of women's participation in government, effectively circumscribing women's political roles. Paula Sanders examines certain legal texts of Muslim jurists, mostly of the eleventh century, to see how they constructed gender. She selects the seemingly arcane but potentially dangerous problem of the ungendered, those who had both male and female reproductive organs-hermaphrodites. The ambiguity of hermaphrodites created a gray area in a world of bipolar divisions of male and female. In setting hermaphrodites into the social order by providing guidelines for ritual and behavior, medieval Muslim jurists reaffirmed gender boundaries and hierarchies.

The following cluster of chapters is set in the Mamluk period (12501517) in Egypt. Huda Lutfi shows how prescribed gender boundaries were broken in practice by medieval Cairene women. Extracting information on female behavior from a treatise by the fourteenth-century scholar Ibn al-Haij, she finds that women shaped their habits and rituals according to their own needs and participated actively in public life, much to the chagrin of her scholar. Carl Petry sees gender as an important factor in shaping the strategies of the Mamluk elite for managing family property. Because of the endemic violence of Mamluk politics and the consequent high male mortality, women, whose chances of surviving were better, often became caretakers of estates and supervisors of trusts. In this way, they ensured family stability and class continuity, in turn augmenting their own status in Mamluk society. Jonathan Berkey describes how women pursued education through informal as opposed to institutional channels. Many specialized in transmitting hadith (Traditions), an endeavor that may have been permitted, according to Berkey, in part because it combined the skill of memorization with the advantage of age.

The chapters on the modern Middle East are grouped by region, starting with two on Ottoman and Turkish women. Donald Quataert argues that women played a crucial role in nineteenth-century Ottoman manufacturing, especially in handicraft, textile, and carpet production. By focusing on household economies and small workshops, he challenges the view that manufacturing and its labor force declined during this period. Quataert also finds that, with regional variation, many households showed flexibility in the division of labor. Nermin Abadan-Unat examines the educational and legal reforms of the Turkish Republic, assessing their impact on the position of women of various classes in Turkish society. She shows how Ataturk's secularizing path, unique to the region, has come under attack by Islamists, threatening to reverse earlier gains for women. 
Regarding Iran, Erika Friedl has personally witnessed major social changes telescoped into decades in the tribal-rural Iranian community that she has studied for the past twenty years. She argues that overlapping and changing productive systems help to explain an increasing circumscription of women's roles and behavior. The relative freedom of many tribal-rural women has largely been based on socioeconomic necessity and is not deeply embedded in ideology. It is fragile and easily lost with changes in social circumstances, as the past two decades have shown. Mary Hegland looks at the public-private dichotomy as myth and ideology in a village. The myth obscures women's real political contributions, and the ideology functions to control women and their activities, creating a reservoir that can be tapped for appropriate political purposes.

The final section of the volume focuses on the Arab world. Judith Tucker attempts to recapture the female experience of the family in eighteenth- and nineteenth-century Palestine. Women could draw support and protection from family members to temper a husband's patriarchal control. Her evidence shows the importance of a number of different affective family relationships. The next chapter, set in late-nineteenth-century Algeria, echoes Ahmed's suggestion that mysticism gave women greater freedom. Julia Clancy-Smith examines the life of Lalla Zainab, an Algerian saint, mystic, and learned woman, documenting her struggle to succeed her father as head of a sufi lodge in the face of resistance from her cousin, who promoted his own claims, and French colonial officials, who backed the cousin. Zainab successfully defended her inheritance, drawing on her spiritual authority to transcend indigenous and foreign gender boundaries.

In the first of three chapters on modern Egypt, I sketch changing marital patterns among urban middle-class and upper-class Egyptians in the nineteenth and twentieth centuries. I argue that during this period the notion of marriage based on love and free choice began to displace the older ideal of arranged marriages. Virginia Danielson focuses on the lives of a group of Egyptian performers (among them Umm Kulthum) who dominated the music industry in the 1920s. These women demonstrated a high degree of autonomy in managing their careers, taking advantage of the opportunities that new technologies offered. In the final chapter of the volume, Cynthia Nelson probes the relationship of biographer and memoirist as she examines the life of Doria Shafik, an Egyptian feminist active in the 1940s and 1950s. Shafik fought for political equality for women before being placed under house arrest in 1957. Nelson argues that her feminism was grounded in indigenous culture and was not in opposition to Islam.

Each chapter provides insights into the past, opening new topics for consideration or encouraging reconsiderations of old ones. Together they 
improve our understanding of women and gender in Middle Eastern history. During the early centuries of Islam, once-fluid gender boundaries began to rigidify. Yet they were never impermeable, and in the Mamluk period seemed quite elastic as women of different backgrounds exercised relative autonomy. In modern times, shifting boundaries have mostly moved toward increased equality for women, but not always. Gender relations in the Middle East have proven dynamic, with women's spheres of action contracting and expanding at different moments and rates in response to a variety of factors, including women's acts and attitudes. Although the chapters within are concerned with far more than boundaries, gender boundaries and their changes over time provide one approach to illuminating the past and present of the Middle East. 
Women in Middle

\section{Eastern History}


This page intentionally left blank 